\title{
A rare case of pneumomediastinum after blown tire
}

\author{
(1) Onur Tezel, M.D., 이 Doğan Özen, M.D.
}

Department of Emergency Medicine, University of Health Sciences Gülhane Faculty of Medicine, Ankara-Turkey

\begin{abstract}
Subcutaneous facial emphysema is a well-known consequence of oral and maxillofacial traumatic injury. In some rare cases, the subcutaneous air collection could spread through the retropharyngeal and paralatero-cervical spaces, reaching the mediastinum.A 55-year-old man was presented to the emergency room after a blast injury caused by a blown truck tire while trying to change tires. The chest radiograph demonstrated suspected pneumomediastinum or pneumothorax. A computed tomography scan of the neck and thorax revealed widespread surgical emphysema along the thoracic wall, extending through the mediastinum. The patient was monitored in the Thoracic Surgery Department after surgery and managed with conservative methods. He had no complications on clinical follow-up following hospital discharge. The development of pneumomediastinum after oral or maxillofacial trauma is rare. Nevertheless, given the mortal complications that may develop, clinicians should keep pneumomediastinum in mind in the differential diagnosis.
\end{abstract}

Keywords: Mediastinal emphysema; pneumomediastinum; subcutaneous emphysema; trauma.

\section{INTRODUCTION}

Subcutaneous facial emphysema is a well-known consequence of oral and maxillofacial traumatic injury. In rare cases, the subcutaneous air collection can spread into the retropharyngeal and paralatero-cervical spaces, reaching the mediastinum. This clinical condition, defined as the presence of air in the mediastinal space, is known as pneumomediastinum or mediastinal emphysema ${ }^{[1,2]}$ and is a rare but possibly life-threatening condition that can mimic other serious conditions such as cardiac tamponade or pneumothorax. It can be caused by penetrating or blunt trauma or can occur spontaneously in a healthy subject. ${ }^{[2]}$ We present a case of pneumomediastinum that was caused by a rare mechanism.

\section{CASE REPORT}

A 55-year-old man presented to the emergency room following a blast injury caused by a blown truck tire (of unknown pressure) that he sustained while trying to change the tire. The patient was initially evaluated by the first responder team and then brought to our trauma center emergency room. He complained of left-side facial and neck pain. He had no difficul- ty breathing and no excessive bleeding. He had not lost consciousness and remembered everything about the incident. On presentation, his vital signs were normal (Blood Pressure $13 \mathrm{l} / 7 \mathrm{I} \mathrm{mmH}, \mathrm{SpO}_{2} 92 \%$, pulse $82 \mathrm{bpm}$, and temperature $36.6^{\circ} \mathrm{C}$ ). His Glasgow Coma Scale was 15, his respiratory rate 16, and his Revised Trauma Score 8. On examination, crepitation was palpated through the left side anterior neck, and a little tenderness was detected on the left side of the face and neck. A laceration extended from the left submandibular area to the left labial commissura (Fig. I). The heart and lungs sounded normal. An oral examination revealed no tooth loss or active bleeding.

A chest radiograph suggested pneumomediastinum or pneumothorax (Fig. 2a). A computed tomography (CT) scan of the neck and thorax revealed widespread surgical emphysema along the thoracic wall that extended through the mediastinum and upwards into the neck, involving both superficial and deep compartments up to the skull base (Fig. $2 b$ and c). No pneumothorax was detected.

After diagnosing the patient with pneumomediastinum, thoracic and reconstructive surgeons were called to review the

Cite this article as: Tezel O, Özen D. A rare case of pneumomediastinum after blown tire. Ulus Travma Acil Cerrahi Derg 2021;27:374-376.

Address for correspondence: Onur Tezel, M.D.

Sağlık Bilimleri Üniversitesi Gülhane Tıp Fakültesi, Acil Tıp Anabilim Dalı, Ankara, Turkey

Tel: +90 312 - 3042000 E-mail: dr.onurtezel@gmail.com

Ulus Travma Acil Cerrahi Derg 202I;27(3):374-376 DOI: 10.14744/tjtes.202I.0190I Submitted: 27.03.2020 Accepted: 22.12.2020

Copyright 2021 Turkish Association of Trauma and Emergency Surgery 
patient, whom they evaluated at the emergency room. It was decided that a reconstructive surgeon would operate on the patient and the follow-up treatment would be coordinated by the Thoracic Surgery Department. The surgery took $3 \mathrm{~h}$ and 14 min and had no complications.

After surgery, the patient was admitted to the thoracic surgery ward, and a control CT was obtained 2 days later. Following confirmation that the pneumomediastinum had decreased, the patient was discharged 3 days after surgery without any complications. A control chest radiograph 2 weeks later showed that the condition had completely resolved (Fig. 2d).

\section{DISCUSSION}

Pneumomediastinum, also known as mediastinal emphyse$\mathrm{ma},{ }^{[1,2]}$ is defined as the presence of air in the mediastinal space.

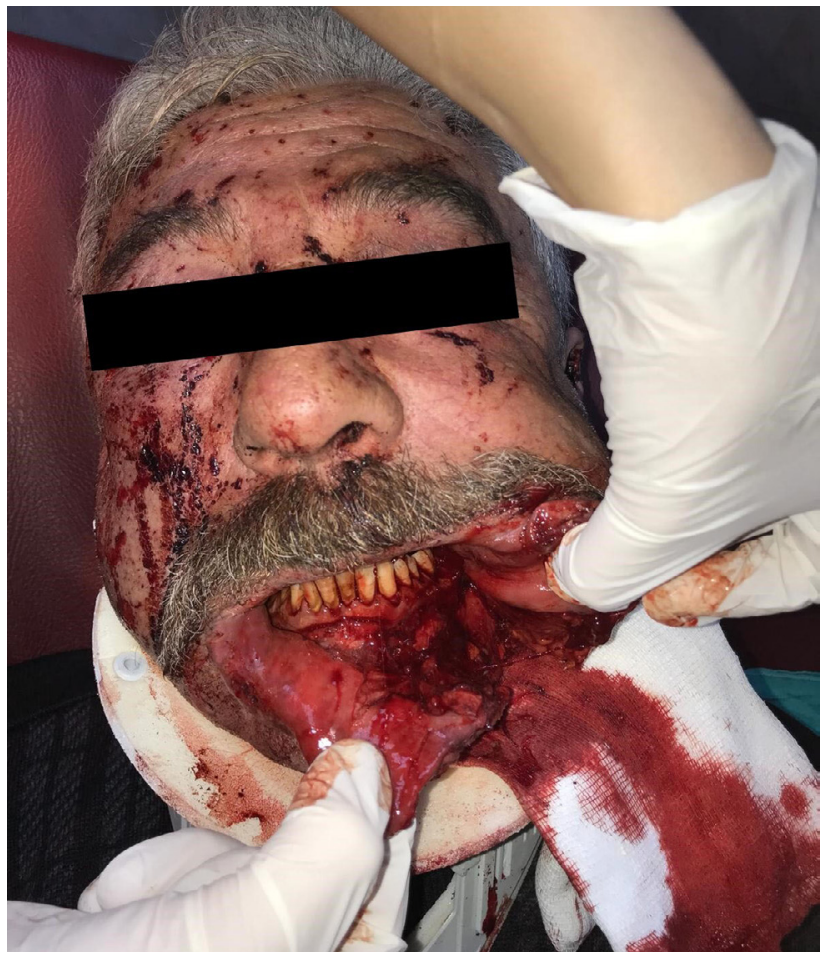

Figure 1. Patient at first presentation to the emergency room.
Several authors have reported onset of cervical and mediastinal emphysema due to iatrogenic causes such as facial trau$\mathrm{ma}^{[3-5]}$ and orthognathic surgery, ${ }^{[3]}$ especially in the mandibular region. Such trauma is typically blunt or penetrating. To the best of our knowledge, our case is the first to document external barotrauma causing pneumomediastinum. Barotrauma is tissue damage caused by a difference in pressure between a gas space inside the body and its surrounding external environment. When pressurized air is forced beneath the dermis, subcutaneous emphysema may result. ${ }^{[6]}$ If a large amount of air is injected, it may disperse into deeper structures through tissue planes, reaching distant sites such as the mediastinum or pericardium, and it may even cause a pneumothorax. ${ }^{[7]}$

In most cases, the air that causes pneumomediastinum is introduced through a fractured facial bone, ${ }^{[3-5,8]}$ but in this case, the subcutaneous air was introduced through the laceration on the left mandibular area without any bone fracture. The pressurized air expanded through the submandibular area, which connects with the retropharyngeal and parapharyngeal spaces, eventually reaching the upper mediastinal space.

Evaluation and diagnosis of the condition are best accomplished with chest X-rays and CT imaging, ${ }^{[2]}$ which we used in this case.

Management of a patient with pneumomediastinum varies according to the development of complications. Although it is typically a benign condition that needs only symptomatic treatment, interventions such as skin incisions, chest tube drainage, or even thoracotomy may be needed for decompression. ${ }^{[2,9,10]}$ As Takada et al. ${ }^{[1]}$ describe in their case series, however, most cases of subcutaneous emphysema resolve within 5 days. Similarly, our case did not require any surgical interventions for decompression.

Continuous monitoring of blood oxygen saturation and administration of adequate antibiotics are necessary for patients with pneumomediastinum and/or subcutaneous emphysema associated with any kind of traumatic lesion to the intraoral mucosa or midfacial skeleton. ${ }^{[12,13]}$ Our case was managed through such conservative methods.
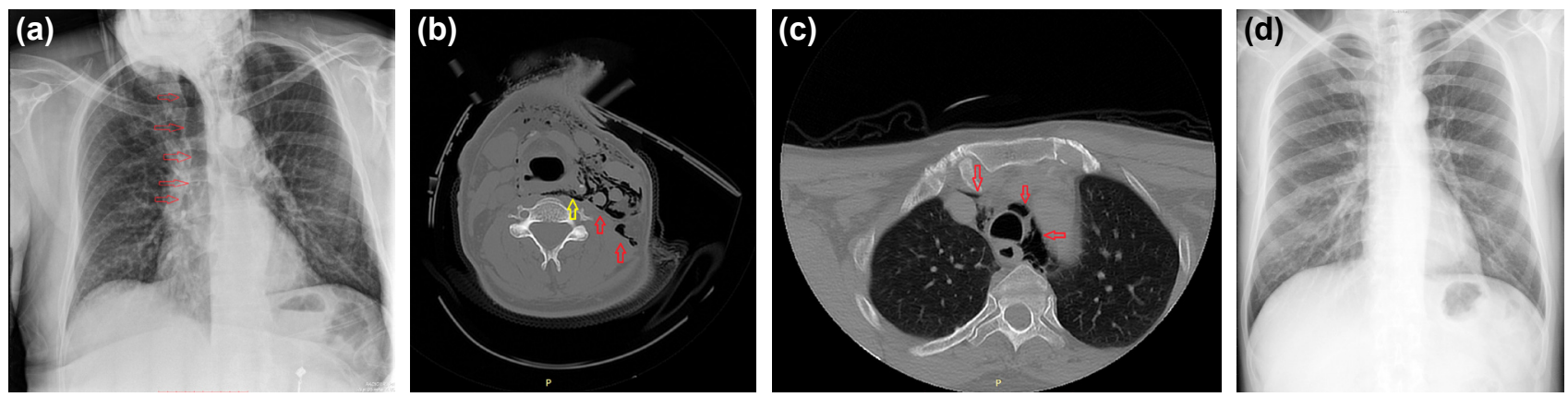

Figure 2. (a) A plain chest X-ray showing hypodense area consistent with mediastinal emphysema on the right side of the upper mediastinal space (arrows). (b) Subcutaneous (red arrows) and retropharyngeal (yellow arrow) emphysema. (c) Mediastinal emphysema (arrows). (d) Control chest radiograph after 2 weeks showing complete recovery from pneumomediastinum. 


\section{Conclusion}

While the development of pneumomediastinum after oral or maxillofacial trauma is rare, given the possibility of fatal complications, clinicians should keep pneumomediastinum in mind during differential diagnosis.

Informed Consent: Written informed consent was obtained from the patient for the publication of the case report and the accompanying images.

Peer-review: Internally peer-reviewed.

Authorship Contributions: Concept: O.T.; Design: O.T., D.Ö.; Supervision: O.T.; Resource: O.T.; Materials: D.Ö.; Data: D.Ö.; Analysis: O.T.; Literature search: D.Ö.; Writing: O.T., D.Ö.; Critical revision: O.T., D.Ö.

Conflict of Interest: None declared.

\section{REFERENCES}

1. Procacci P, Zanette G, Nocini PF. Blunt maxillary fracture and cheek bite: Two rare causes of traumatic pneumomediastinum. Oral Maxillofac Surg 2016;20:91-6. [CrossRef]

2. Kouritas VK, Papagiannopoulos K, Lazaridis G, Baka S, Mpoukovinas I, Karavasilis V, et al. Pneumomediastinum. J Thorac Dis 2015;7:S44-9.

3. Ong WC, Lim TC, Lim J, Sundar G. Cervicofacial, retropharyngeal and mediastinal emphysema: A complication of orbital fracture. Asian J Surg 2005;28:305-8. [CrossRef]

4. Roccia F, Diaspro A, Pecorari GC, Bosco G. Pneumomediastinum and cervical emphysema associated with mandibular fracture. J Trauma 2007;63:924-6. [CrossRef]

5. Rashid MA, Wikström T, Ortenwall P. Pneumomediastinum after nasal fracture. Eur J Surg 1999;165:903-4. [CrossRef]

6. Maunder RJ, Pierson DJ, Hudson LD. Subcutaneous and mediastinal emphysema. Pathophysiology, diagnosis, and management. Arch Intern Med 1984;144:1447-53. [CrossRef]

7. Chen SC, Lin FY, Chang KJ. Subcutaneous emphysema and pneumomediastinum after dental extraction. Am J Emerg Med 1999;17:678-80.

8. Switzer P, Pitman RG, Fleming JP. Pneumomediastinum associated with zygomatico-maxillary fracture. J Can Assoc Radiol 1974;25:316-8.

9. Perna V, Vilà E, Guelbenzu JJ, Amat I. Pneumomediastinum: Is this really a benign entity? When it can be considered as spontaneous? Our experience in 47 adult patients. Eur J Cardiothorac Surg 2010;37:573-5.

10. Macia I, Moya J, Ramos R, Morera R, Escobar I, Saumench J, et al. Spontaneous pneumomediastinum: 41 cases. Eur J Cardiothorac Surg 2007;31:1110-4. [CrossRef]

11. Takada K, Matsumoto S, Hiramatsu T, Kojima E, Watanabe H, Sizu M, et al. Management of spontaneous pneumomediastinum based on clinical experience of 25 cases. Respir Med 2008;102:1329-34. [CrossRef]

12. Anderson JA, Tucker MR, Foley WL, Pillsbury HC 3rd, Norfleet EA. Subcutaneous emphysema producing airway compromise after anesthesia for reduction of a mandibular fracture. A case report and review of the literature. Oral Surg Oral Med Oral Pathol 1991;71:275-9. [CrossRef]

13. Reznick JB, Ardary WC. Cervicofacial subcutaneous air emphysema after dental extraction. J Am Dent Assoc 1990;120:417-9. [CrossRef]

\section{OLGU SUNUMU - ÖZET}

\section{Araç lastiği patlaması sonrası nadir bir pnömomediastinum olgusu Dr. Onur Tezel, Dr. Doğan Özen \\ Sağlık Bilimleri Üniversitesi Gülhane Tıp Fakültesi, Acil Tıp Anabilim Dalı, Ankara}

Yüz bölgesinde görülen cilt altı amfizem, oral ve maksillofasiyal travmatik yaralanmanın iyi bilinen bir sonucudur. Bazı nadir durumlarda, cilt altı hava koleksiyonu retrofaringeal ve paralatero-servikal boşluklara yayılabilir ve mediastene ulaşabilir. Elli beş yaşında erkek, kamyon lastiğini değiştirmeye çalışı̆̆ı sırada lastiğin patlaması ile oluşan yaralanma sonrası acil servise getirildi. Göğüs radyografisinde şüpheli pnömomediastinum ve pnömotoraks tespit edildi. Boyun ve toraks bilgisayarlı tomografi taraması ile torasik duvar boyunca mediastene uzanan yaygın cerrahi amfizemi tespit edildi. Hasta ameliyat sonrası göğüs cerrahisi bölümünde izlendi ve konservatif yöntemlerle tedavi edildi. Hastaneden taburcu olduktan sonra klinik takibinde herhangi bir komplikasyon tespit edilmedi. Sonuç olarak, oral veya maksillofasiyal travma sonrası pnömomediastinum gelişimi nadirdir. Bununla birlikte, gelişebilecek ölümcül komplikasyonlar göz önüne alındığında, klinisyenler ayırıcı tanıda pnömomediastinumu akılda tutmalıdır. Anahtar sözcükler: Mediatinal amfizem; pnömomediastinum; subkutanöz amfizem; travma.

Ulus Travma Acil Cerrahi Derg 2021;27(3):374-376 doi: 10.14744/tjtes.2021.01901 